\title{
Myth today and together
}

Pete Bennett, University of Wolverhampton

Julian McDougall, Bournemouth University

\begin{abstract}
This article presents a theoretical evaluation in practice, in the form of a project whereby Barthes' collections of Mythologies $(1973,1979)$ were 'reimagined' by academics, teachers and students from (and for) the contemporary arts and media/culture landscape. Sections of the article rework extracts from two 'bookending' essays in a published collection, which, in this contribution, forms one strand of a broader research project and as such is placed in discursive and pedagogic conflict with the other data generated by the research. This 'data' is textual, generated by two participant groups - self-identified published 'experts' from the field of art, media and cultural studies, and groups of 'inexpert' student/teacher collaboration - both working to the same 'brief' but in different contexts. The 'expert' group responded to a conventional call for chapters, accepting the invitation to contribute to an orthodox scholarly 'reader'. The group of 'inexperts' used a wikispace to respond collaboratively, blurring boundaries between teacher and student, author, myth and text. Our interpretation of the textual material produced by working, writing and myth-making in these ways identifies the dominant emerging discourses articulated by the data. In assessing these themes, we ask what is a myth today, in art's 'problematic relationship to knowledge', what constitutes theory and who has the authority to impose theory on art as myth? Our tentative answers to these questions go
\end{abstract}


beyond a 'reimagining' of Barthes' intervention to lead us to propose some

implications for values and practices in learning and teaching in arts, media and culture, closing in further on a 'pedagogy of the inexpert'.

\section{Keywords}

Barthes

myth

theory

expertise

arts and media

pedagogy

Rancière 
Responding to an open call for abstracts, a range of published 'experts' in the field of Arts, Media and Cultural Studies produced 28 essays for a new version of Mythologies, framed by the 'old' genre of an edited academic 'reader' (Bennett and McDougall 2013, 2015).

Second, and separately, three groups of Art, Media and Cultural Studies students responded to another open call to identify contemporary mythologies with significance in the lifeworld and then work with their teachers to 'scaffold' these theoretically. In this element, students were originators of the myths, and teachers the academic 'experts' on how to articulate them, but with less direct 'Barthesian' direction than their 'elite' counterparts.

The two forms of discursive data are not only framed by very different configurations of author - expert - theory but also by different spatial arrangements - the traditional scholarly 'reader' with its attendant relations of publisher - editor - author - reviewer and the anonymous and potentially more 'organic' alternative in the form of a Wiki, harnessing - to an extent - authorless 'crowd sourcing' strategies.

Our analysis interrogates this data to elicit findings in relation to myth, theory and expertise -with specific attention on the significance of these in contemporary Arts and Media education. We arrange our findings in relation to three key questions:

1. What do the different new mythologies generated by the authored and authorless versions tell us about the phenomenology of myth in art and culture today?

2. What do these different processes for 'doing theory' on art and culture tell us about epistemology, power and textual authority with regard to art education's 'problematic relationship to knowledge' (Hughes 2014)? 
3. What is the significance of expert/inexpert discourse for the values and practices (Drew and Shreeve 2012) of pedagogic ways of 'doing theory' in and on art and culture?

\section{Barthes: Myth}

Both Mythologies (1957) and our project are compilations of responses to contemporary concerns around art in media culture. Both include a theoretical statement 'Myth Today', but in both cases these emerge from the readings rather than from pre-framing them. Ask now, as Barthes did, 'What is a myth today?'; one answer is Barthes himself, who has become to some extent the key to all mythologies. Barthes is comparable to the Eiffel Tower he so artfully interprets. Our authors and students were more or less knowingly treating Barthes in the same way. In so doing they were adding also to two very different English 'extensions' of Barthes. Masterman (1985), with a collection of teachers and academics, produced Television Mythologies: Stars, Shows and Sign, bringing Barthes' methods to bear on popular British television. Masterman wrote of the specific impact of these 'readings': 'What Mythologies demonstrated was the centrality of power relations...' and also how 'Mythologies cut decisively through these carefully constituted distinctions between politics and history'. These 'French Lessons' were still evident in Michael Woods' keynote at the recent Barthes 100 conference. In the year of Barthes' centenary, those assembled may have found both poignancy and irony in Masterman's dedication: 'In living memory to Roland Barthes who understood that a critic needs also to be a fan'.

Adair's Myths and Memories (1986) is a quirkier homage to Barthes (and George Perec), written with Barthesian key and intention, to unveil what Adair calls 'tiny 
shards of a common nostalgia'. Adair had rehearsed a year earlier for the role of the mythologist with an April Fool's Day contribution to Sight and Sound, apparently by Barthes, entitled 'Nautilus and the nursery': 'Carry On... is Utopian cinema par excellence. Which is not to say very much: the question ought to be, which Utopia?' (Adair,1985: 131).

Our project generated various forms of writing, from teachers, students and both together, all participants knowingly aware of their status as forming a new 'Mythologies' and in working with myth as a double system. And while we were conscious of the potentially canonical character of the Barthes text within a number of disciplines, in word and deed Mythologies (Barthes, 1972) defies classification, its Formatted: Font: Not Italic 'double system' in effect a perpetual motion machine. Moreover, Barthes himself epitomizes the engaged exploratory commitment that we were inviting, offering a down payment against Deleuze's subsequent challenge that 'We lack creation. Resistance to the present' (Deleuze and Guattari 1994: 108). Here is a writer who explicitly resisted even the notion of his oeuvre, which he saw as a 'move from a contingency of writings to the transcendence of a unitary, sacred product' (Barthes 1977: 136). Even the tour de force that is Myth Today is put firmly in its place as merely an attempt 'to define contemporary myth in methodical fashion and thus "I have naturally placed this particular essay at the end of the book, since all it does is systematize topics discussed previously"'(Barthes 1972: 10).

Although Barthes was variously classified, Derrida's evaluation is perhaps the fairest: 'Roland Barthes traversed periods systems, modes, "phases" and "genres"... his first move was to recognise in each of these their necessity or richness, their critical value and light, in order to turn them against dogmatism' (Derrida 1981: 282). 'I delight ceaselessly, endlessly', he said, 'in writing as in a perpetual production, in an 
unconditional dispersion, in an energy of seduction which no legal defence of the subject I fling upon the page can any longer halt' (Barthes 1977: 136). For Barthes, in Mythologies 'the best weapon against myth is perhaps to mythify it in its turn' to track 'the progress of their solidification, their densification throughout historical discourse' (1972: 42). Barthes admits to 'a mythology of the mythologist' but in doing so proclaims, 'What I claim is to live to the full the contradiction of my time, which may well make sarcasm the condition of truth' (1972: 10).

Barthes is a master of faux classification, a systems builder with a profound dislike of systems, whose sarcasm is sometimes difficult to spot, particularly for those buying into the myth of Barthes: 'Teacher, man of letters, moralist, philosopher of culture, connoisseur of strong ideas, protean autobiographer...' (Sontag 1993: vii). Though he complains that 'we cannot yet draw up the list of the dialectal forms of bourgeois myth', he then lists its seven principal rhetorical forms! (Barthes 1972: 151). By the time he is inducted as a professor at the College de France even the linguistic scientist has turned artist:

The semiologist is an artist. He plays with signs as with a conscious decoy, whose fascination he savours and wants to make others savour and understand. (Sontag 1993: 475)

We have written recently with practitioners about the potential opportunities offered by these open emancipatory approaches, our 'pedagogies of the inexpert'. In Doing Text we explicitly identify Barthes 'as much more of a transitional figure and are keen 
not to saddle him with every limitation of every lightly taken position' (Bennett and McDougall 2016). In fact, Barthes' mantra is simple: 'I can only repeat to myself the words which end Sartre's No Exit: Let's go on' (Barthes 1977: 136). Ultimately, that book finds its model in Deleuze and Gauattari's notion of the rhizome, delivered by Cormier as 'The Rhizomatic Model of Education':

The rhizome metaphor, which represents a critical leap in coping with the loss of a canon against which to compare, judge, and value knowledge, may be particularly apt as a model for disciplines on the bleeding edge where the canon is fluid and knowledge is a moving target. (2008)

However, our' New Mythologies_' (Bennett and McDougall: 2013, 2015) and indeed

Formatted: Font: Not Italic Barthes' original are also contributions to this 'unattributable' Deleuzian project. These 'assemblages'-, these 'multiplicities' are consciously made, as Deleuze and Guattari insist they must be, 'but we don't know yet what the multiple entails when it is no longer attributed, that is, after it has been elevated to the status of a substantive' (2004:4). They are also methodologies mindful of their respective functions: 'To attain the multiple, one must have a method that effectively constructs it' (Deleuze and Guattari 2004: 22). As Deleuze and Guattari point out, 'The rhizome operates by variation, expansion, conquest, capture, offshoots' and 'pertains to a map that must be produced, constructed, a map that is always detachable, connectible, reversible, modifiable, and has multiple entryways and exits and its own lines of flight' (2004: 21). New territories often need not new maps but rather new cartographies. This may as Neil Badmington suggests remain the reason for Barthes' continued relevance: 
Re-reading Mythologies while working on the expanded English edition last year brought home to me why the text is still relevant: while much separates the 1950s from the present, Western culture remains riddled with appeals to 'common sense' and 'human nature'. Myth endures. But a euphoric alternative rages in Mythologies. (Badmington 2010: 1)

\section{Method}

The formal academic reading of art and culture, contemporary or otherwise, can be understood as a 'figured world' - 'socially and culturally constructed realms of interpretation' (Holland, in Holland-and Quinn, 1998: 52), which have limiting effects on agents. Our authors in the edited collection are speaking the interpretive discourse of the culture-scholar within the idioms of such an imposed (and profoundly constructed) realm, while our students are limited by their proximal relations to 'expertise'.

The formal educational analysis of myth in the 'everyday', however potentially progressive, has become institutionalized in the 'figured world' of the academy and its manifestation in the arts and media studio/classroom. Our interest here lies in the potential for the 'use' of this 'reimagining' to create a 'third space' where such figured worlds might intersect.

\section{Findings: Theory and the expert}


From the essays produced by our 'expert academics' (Bennett and McDougall 2013; 2015), we identify four emerging discourses of contemporary mythology. The discourses overlap and are not contained and insulated by such categorization, but they demonstrate our ways of understanding this reimagining of theory, as editorresearchers. This is not, of course, simply demonstrative of contemporary culture, or even readings of such. What we deconstruct here is a textual field largely of our making. While the invitation was open, the editorial process of commission, redrafting and acceptance was configured along shifting axes, seeking to present sufficient international range, to avoid thematic duplication, to ensure the gaze of the reader is upon the 'now'. As a result, there are 'readings of culture' that were written but do not appear in the collection. They may be published elsewhere, or not at all. Other essays were 'refocused', cut down or extended, to comply with our editorial preferences, to be 'more Barthesian', to be less 'academic'. To this end, we asked authors to bracket their academic instincts (to reference, to paraphrase, to show how they have mined a 'field') and instead to 'do Barthes' on contemporary myth. We allowed minimal footnotes, because Barthes used these, but we reserve the luxury of academic references to ourselves in this article, imposing a scholarly authority with this apparently more scientific 'register'. What we present is, then, a 'figured world' partly of our own construction and thus we can no more claim to 'know' myth today than Barthes did or could. Our only recourse is to get inside it.

This article is quite different to the edited collection; we are attempting a reflective theorizing of the project, with the published essays put in a dialogic relation to the anonymous online postings by the 'non-expert' cohort. To this end, giving more prominence to the book essays would skew this commentary on theory-making as 
research, but nonetheless some coverage of the range of myths constructed by the academic authors is required (reference for all: Bennett and McDougall 2013, 2015).

Authors updated 'The Face of Garbo' with Julian Assange, discussed the driving and

uniting idea of fame at the heart of the X Factor (2004-) myth, contrasted the mythology of Fair Trade with claims to equality, and offered up Batgirl as a split signifier. Others presented education as 'the master-myth of our time', theorized multiple Sherlocks and deconstructed the myth of perpetual (digital) contact. We published essays on Zombie Walks; Press Freedom; Higg's Boson and Top Gear (2002-) ('the cultural politics of being a knob' - ahead of its time as it turned out). One author returned to the Face of Garbo to overwrite Barthes' essay with a treatment of Kylie; others myth-made around the figure of the 'mad genius' in film and the Museum of Champions at Hyde Park_and updated 'Striptease' with essays on modern strip clubs and Pippa Middleton's posterior. Barthesian reflections were published on the passport; the media outpourings of Alain De Botton; the (Yorkshire) Ripper myth; and Noomi Rapace - another 'Face of' essay. The Radio 4 pips, Citroen Picasso (updating Barthes 'New Citroen') and Jessica Lynch were mythologized. Other contributors 'did Barthes' on the 7/7 London bus bombing; Mary Quant and Vivienne Westwood; the scandal around the Lithuanian city of culture, Vilnius; the video statement from a female Palestinian suicide bomber; and the broader enduring myth of 'toxic childhood'.

These 28 'expert' essays can be arranged into four discursive categories - the temporal discourse, in which Barthes' approach is maintained but 'updated'; a discourse of secondary encoding, in which Barthes is more prominently 'appropriated' from within; a more political discourse of 'unmasking' towards a form of emancipation; and a more frivolous 'outlaw' discourse. 


\section{Temporal: Remaining a type of speech}

Essays in this category most faithfully reproduce the euphoric rage in 'doing myth' today on Kylie, Alain de Botton, the Xsara Picasso and Noomi Rapace. Taken together, these and other readings in this category share an impulse to 'update' or extend.

The 'classic props of the music hall' have been replaced by slick routines and lighting which serve to frame a vista of surgical body enhancement and augmentation

This essay starts from Barthes' discussion of myth as semiological system and extends it to consider the history of similar characters and also the impact of their appearance across media forms and across cultural boundaries in a globalized media ecology

This essay defines the myth of zombie walks as underpinned by a series of binary oppositions, such as the individual/hive; the political/recreational; and the technological/homemade. It situates the zombie walk myth within these wider mythologies and argues that it is emblematic of the tension between individual and society that underpins Western culture (e.g. the American Dream; capitalism) and represents a modern subversive response to these social structures. 
Myth remains the 'master category' here, the mythologist the 'watcher at the crossroads' (Sontag 1993: xxi, xxiii).

\section{Secondary encoding: The reappraisal and affirmation of signification}

We identify this discursive framing at work in essays contributed to the collection on the passport, The X Factor, Julian Assange and Hyde Park. Across these readings, and more such 'forays' we observe more than an updating to the times but rather a reworking of the 'mantle of the expert':

Joker's bullet marked a point, a punch (coup de poing), what we might call a punctuation in the sentence of Batgirl's narrative; it severed the 'Bat' from the 'Girl', and indeed for the next twenty-five years (a longer period, in fact, than what now figures as the first half of her career) Barbara occupied the second term in this hyphenated pairing. (Brooker, in Bennett and McDougall, 2013, 29).

The very notion of a 'Sherlock for our times' reifies an historical moment as calling for its own distinctive myths, even while Sherlock's present-day narratives can be read as highly reactionary. (Hills, ibid, 42)

'Pippa Middleton's bottom “too bony”, claim French.' The wedding of Prince William and Kate Middleton in April 2011 was a remarkable media event, not least because of the attention given to the sister of the bride's backside; in the sacred space of Westminster Abbey, much of the focus was on the profane, 
subsequently spawning a Facebook appreciation page, at least one Twitter account and a dedicated website. The excitement, speculation and fetishisation reveal something about the order of things - the signification of the body.

(Berger and Readman, ibid, 75)

If the face of Garbo was an Idea, and that of Hepburn, an Event, the face of Assange combines both concepts, being intimately tied [...] His figure would act in this sense as a real semiotic condenser who operates as the symbols do, and whose ultimate meaning is closely linked to the concept of Utopia, understood as the strict opposite of an evil present. One could say that Assange makes Neussüs' old dream come true, and that Utopia has at last found its Marx. (Gomez, ibid, 17)

These extracts most prominently and profoundly speak the very stock in trade of art and media education, that of the textual expert-scholar, the teacher. The endurance of Barthes is here the enthusiasm with which our authors speak this 'advanced' complicity in the form of a metalanguage, which is that of the aesthete but nonetheless compromised by the acceptance of this game of 'hide and seek'.

\section{Political: Stolen language}

We see this more deconstructive impulse in essays devoted to Top Gear, Toxic Childhood, The Digital Age and Press Freedom. Aligned in our thematic 'coding' with similarly 'activist' writings, this work speaks the rage: 
It is difficult to overemphasize the role of education as myth in our era.

Education is the master-myth of our time. Its encompasses everything. It operates as a Heideggerian onto-theological principle. Education is correlated with Being itself. To fall outside the domain of education is to be cast in the role of inferior Other: indoctrinated naif; primitive, if quaint, savage; untutored consumer; uncultivated oik; inarticulate footballer [...] No longer seeking to mask inequalities, education discourses now constantly highlight them within a mythological structure that sustains the very inequalities it claims to challenge with the empty promise of redemption through improvement.

It goes without saying that the media seriously undervalues serious thought. Less noticeable, however, are the myths the media creates when it does tackle cerebral matters. The essay addresses this aspect of the media's standard operating procedure - its depredation of thinking in the guise of thought.

Semiotics becomes a tool in power's hands by bolstering what Said calls 'Blake's mind-forg'd manacles'. One such shackle that Said tried to break is the so-called myth of 'peace' in the Middle East. I analyse his writings against Oslo to show that peace in the region has become sign-governed. Rather than reaching people, it bizarrely satisfies the world's need for a moral theatricality in a Barthesian sense.

But to be aware of the inequality that the Fair Trade myth hides behind is to be armed and prepared to question the status quo. Cocoa and sugar have a long history of workers' exploitation which was exacerbated when the European 
markets developed a deadly desire for sweet goods despite their little dietary value. Nevertheless, chocolate, once tasted, isn't easily forgotten. It isn't so much a case of choosing wisely between chocolate brands, but of being wise to the Fair Trade myth: whatever the name by which trading takes place, if it isn't equal, it just isn't fair. ADD FROM HARDBACK ED

These extracts most keenly observe - and reproduce - the political thrust to vanquish myth 'from the inside'. As Barthes observed that the 'other' can only speak the language of (her) emancipation, our authors here testify in their opposition to the very power of the myth they (apparently) seek to unmask as such, to unveil the masquerade. In a sense this discourse, in being the most starkly combative and oppositional, is the least Barthesian. They seek to do 'something else', more perhaps, to put something of semiotics to work.

\section{Negative space: Outlaw discourse}

Awry from the categories used above to frame our collection, in a certain frivolity, the sense of 'playing' with Barthes, we can locate a shift in some of our contributions, while located above in our discursive framing, also towards something of the 'outlaw discourse':

'Kylie Ecriture', offers a double reading. It deliberately reworks - almost line by line - Barthes' original mythology text 'The Face of Garbo'. In doing so it enacts a myth of Barthes' own writing. However, the subject of the 
international pop singer, Kylie Minogue, is also a marker of a contemporary myth. This reading seeks to update Barthes' earlier account of two iconographic ages (from Idea to event), suggesting of an erotics of detachment, shifting from an order of play to that of surrender.(Manghani, in Bennett and McDougall, 2013, 64)

The cover design of the edition of Mythologies that sits beside my computer as I write includes a stylised image of Greta Garbo's face and as I glance at any one of the many images of Noomi Rapace's face available through my browser, it seems that the two Swedish actors share the same strong facial features. Yet Rapace also shares the facility that Hepburn had to engage with types and also to be individuated. Her image is at once classical and modern. I think she'll go far. (Stafford, ibid, 103)

With the passport in the bin, will we be rid of the nasty myths of national loyalty as well? Unlikely, because like one object can carry different myths, one myth can tie itself to different objects. Barthes knew that, we know that. The myth of national loyalty will thus find another anchor which we then, again, will have to demythologize. (Van Zoonen, ibid, 85)

The way these authors 'take on' a sense of the spirit of his writing all articulate a discourse of reflexive 'knowingness'. As such they are at once less formally Barthesian and also less political in the sense of unmasking distortion. Equally, they are less 'teachable' as analyses of text. However, the disarming of Barthes - the transposing of him into the discourse_- can be read as an emptying - of the Barthes 
myth - in order to re-fill it, rendering his own mythology at once empty and full, akin to the ultimate paradox-signifier, the Eiffel Tower.

\title{
Findings (2): Theory and the inexpert
}

\begin{abstract}
Barthes allows students the realisation that they can look at the world from different angles - that meaning rarely lies on the surface and that culture is a complex web of interconnections. (teacher, wikispace strand).
\end{abstract}

Teachers had been asked to consider Barthes as 'of use' in contemporary Arts and Media education. This starting gambit served to 'frame' their collaborative work with students, just as our call for essays would signpost - and thus attract the 'converted' to - the notion of 'Mythologies' being of value and worthy of 'update'. Thus we must concede that our experiment is loaded - there is little possibility of either selfidentified expert authors or willing research participants from the classroom coming forward to produce an anti-reading. That said, what of the distinction in approach and/or of material between the essay authors/essays and teacher-student collaborators/wikispace uploads?

The process of this strand of data collection was constructed through these 'instructions' for those accepting the invitation to contribute:

- Teachers - introduce your students, in whichever manner you choose, to 'Mythologies' by Roland Barthes. They need to understand the approach - 
'theorizing' everyday life and the construction of symbolic meaning beyond the 'thing itself' into a language of myth.

- Students - identify a 'thing'/text/event/activity that you think of as carrying meaning at a 'mythical' symbolic level in your life today. Crucial=these examples Must be generated by students on their own.

- Teachers and students - work together to produce a full essay or set of notes or any other form of presentation (video, audio, website, images, artefacts) to make your mythology, and upload this to the wikispace.

We can trace very different emerging discourses from those more 'organic' and anonymous contributions. Three ways of articulating/representing can be identified. First, an approach that seeks to accept the status and sociocultural configuration of contemporary myth - at the level of 'common sense' hegemonic representation and 'othering' For example, a film montage of contemporary depictions of teenagers as a coherent social group to be at once feared and protected by the adult culture, an attempt to challenge and reappropriate a mythology from within, by the mythologized - and this, in this reading, the oppressed. This attempt at reappropriation/challenge is profoundly 'inexpert' but still adopts the theoretical discourse it challenges - a 'nontheory' that reinforces the theorization of everyday life - and the idioms of such theory. Second, participants posted a more conventionally 'academic' essay on the mythology of Apple imagery (the Apple of my ' $I$ ') - this attempts to 'second guess' the self-identified 'expert'/'art critic' strand, so here we see more 'apprentice expertise' than inexpert collaboration:

'Smart' in the sense of intelligence, clever and bright. There is no denying, at 
the level of awe and wonder, the ability of micro electronic technology to give us access to so many communication possibilities in such a small mass produced device. Much is said in the mythologisation of technology especially around the cliché that these smartphones contain thousands of times more computing power than was required to land man on the moon - worth considering as one updates our Facebook status, tweets comment on the latest sporting results and wipe out another green pig with a highly vexed bird launched via pixilized catapults. (anonymous wiki collaboration)

Third, some participants opted to produce a more classically 'student' response - a presentation framed entirely by the language game of 'Subject Culture' - the formal, institutionalized analysis of arts and media in 'teacher space'. Here, the 'snare of infatuation' was with the critical discourse itself - for example, with the carefully evidenced (i.e., referenced) analysis from which Barthes's approach may potentially free the mythologist as a reader. One such addressed the 'need' we have for goods in terms of 'status anxiety' (via De Botton) and a dramaturgical model of selfpresentation (which was Goffman's) in an active and engaging way. However, in this response we witness the ability of the subject-oriented discourse to entertain but never 'pin down' the operation of myth, which, held at arm's length, is reduced to currencies of connotation. Indeed, this academic mode of address made incisive analysis more difficult, for, as Barthes says, 'Myth is not defined by the object of its message, but by the way in which it utters this message' (1972: 109).

Three different versions of 'inexpert' myth emerge. $\underline{A}$ 'free response' attempting to challenge mythology 'from within', a more conventional academic response seeking 
to mirror, to inhabit, the conventions of the 'expert' collection and an approach that is inexpert in the sense that power is deferred to the 'textual authority' of the academic fields at work - those of arts and media education in their institutionalized, hegemonic forms

\section{Questions of pedagogy}

In occupying particular subject positions, teachers and pupils reproduce them; it is only through being occupied that these positions continue to be a part of social structure. So discourse in turn determines and reproduces social structure. (Fairclough 1995: 38)

The discourses we identify above are not 'organic'. Rather, they are the product of a particular mode of interpretation. This mode is partly determined by our own editorial practices - rights and obligations, in Fairclough's terms, and more broadly determined by our respondents' reproducing layers of teacher/student positioning - that of their own self-attributed and author, professional or apprentice status (the confidence to bear witness to one's own expertise) and also that of Barthes as the vertical discourse to 'adopt' or to 'get inside'. Nor is the sample randomized or controlled. Rather, it is self-selecting on one level (academics and teachers responding to invitations for themselves and/or on behalf of their students) and filtered on another (editorial approval, for the 'expert' group). Thus, we can interrogate the discursive framing of myth as encoded through a 'received' language. Here, we want to suggest some 
implications of this research for the (non)discipline of arts and media in higher education.

The tension in our work arises from the 'use' of a canonical text - Mythologies. In other words, what we want to do with theory, and with Barthes, by problematizing how theory 'gets done' nevertheless starts out from a canonical position. In giving authors 'free reign' to write a contemporary mythology of any length between the shortest and longest of Barthes' equivalents, and students the privilege of anonymity, our objective has been to 'capture' myth in between and across contexts and discourses. The identities (and stories told implicitly) of our contributors understanding themselves as academics, writers, students becoming academics, critics, more or less 'expert' - frames the presentation and remediation of art and culture in everyday life.

But, how is this 'of use' to arts and media education?

\section{On doing better}

Despite our inclusion of student mythologists, we still frame this project in orthodox pedagogic relations - the theoretical 'scaffold' is built by the accredited expert in the form of the teacher; the student's power is limited to the selection. Equally, while we resist the enclosure of Mythologies in the manifestation of semiotics as a 'nonprocedure' (Gauntlett 2015: 18), handed down in a vertical discourse (Bernstein 1996) to our students as a kind of 'toolkit', it is certainly necessary to justify this experiment also in the light of one aspect of Turner's self-depreciating lament about the pedagogical orthodoxy at work around the study of culture:
Comment [K6]: Please confirm whether the changes made to the sentence are correct. CORRECT

Comment [K7]: The publication year of Bernstein (1990) has been changed to match the publication year Bernstein (1996) given in the reference list. Please confirm whether this is correct. CORRECT 
As teachers, charged with demonstrating how culture could be analysed, we were especially fortunate because we had a handy party piece available to us. When we introduced our students to semiotics as a simple technique of textual analysis, we could cruise over a wide range of popular cultural texts, demonstrating the kinds of information this analytical tool could generate. Teaching semiotics at the same time as we investigated what it could tell us about contemporary popular culture had the dual benefit of making us appear both knowledgeable and cool. Better still, it was not long before the students could do it too, and so our knowledge was attainable rather than elite. (2012: 82-83)

The operative marker, of course, is the past tense - desired by Gauntlett and stated as a historical fact by Turner. Our edited book is, importantly, just one element of the comparative broader research project we have discussed here, and always intended as a comparative 'data set' and not an 'output' end in itself, but nonetheless we must bear witness to the pervasive tone of the expert-apprentice discourse and the 'disciplinary gaze' (Bowman 2012: 6) we ultimately do little to disrupt.

So, how could the reaffirmation of Barthes be a liberating act for arts and media education? Rancière's (2009) ' 'ignorant schoolmaster' parable requires that the teacher 'must always be one step ahead', in other words re-distancing knowledge because the student 
is the one who does not know what she does not know or how to know it [...] he is the one who knows how to make it an object of knowledge at what point [...] knowledge that cannot simply be ordered in accordance with the ascent from the simplest to the most complex. (2009: 8-9)

Key to this is the transparent acceptance of the profoundly unequal pedagogic relation, pedagogic practices and values as the 'carrier' of democracy, not the manifestation of it somewhere/somehow pre-existing (Simons and Masschelein 2011). Elsewhere, we have proposed an analogous dialogic between 'the work' made by artists and students together and the making of learning as a similarly fluid and collaborative endeavour, which can get us closer to Rancière's indiscipline via a more 'porous' approach to expertise (Orr and McDougall 2014; McDougall and Potter 2015; and see Rancière's elaboration in Bingham et al. 2010). Such a (more) radical pedagogy for arts and media education cannot maintain 'stupefying distance', which can 'only be bridged by an expert':

The ignorant schoolmaster is named thus $[\ldots]$ because he has uncoupled his mastery from his knowledge $[\ldots]$ he does not teach his knowledge, but orders them to venture into the forest of things and signs. (Rancière 1991: 11)

Adopting such a stance, we are compelled to say that the 'significance' of this project is precisely in the 'reimagining' of the expert-scholar position, just as Barthes sought to 'empty out' his own mastery. The research is 'of use', then, as an experiment that shows the working of how theory gets 'done' between arts educators and students.

Comment [K10]: McDougall and Potter (2015) has not been included in the Reference List, please supply complete publication details. 
At stake here is what our 'resurrection' of Barthes does to order, validate and exclude in the domain of arts and media education. In the attempt to undo the 'pseudoscientific' orthodoxy of Barthesian semiotics towards a pedagogic indiscipline, we seek to mirror the kinds of negotiated collective practice at work in the studio, towards a more curatorial approach to the 'problem of knowledge' (Hughes 2014).

Returning to the key research questions we started out with, we can tentatively suggest from the writing we take as 'findings' that

- Our new mythologies tell us that myth can be and is generated in art and culture today and by students and teachers through a more fluid and negotiated curation of expertise but this negotiation is always/already discursively framed by the 'Eiffel tower effect' of Barthes.

- These different and new processes for 'doing theory' on art and culture can only be fostered by a more willfully indisciplined epistemology to go beyond art education's 'problematic relationship to knowledge' (Hughes 2014) towards 'getting inside' knowledge itself.

- Doing theory on art and culture with pedagogically 'inexpert' values and practices can only work if the theory is re-drawn as 'the work' - when curated, this will be different - for some, better or worse - than the previous cohort. At the same time the function of the educator in 'encoding' must be explicit as a practice, equally transparent to the fine artist or film-maker's craft. 


\section{References}

Badmington, N. (2010), 'Why is the Church like margarine?',

http://www.apieceofmonologue.com/2010/02/badmington-on-roland-barthesand.html. Accessed 2 November 2012

Barthes, R. (1972), Mythologies, London: Jonathan Cape.

(1977), Roland Barthes, New York: MacMillan.

(1979), The Eiffel Tower and other Mythologies, California: California

University Press.

Bennett, P. and McDougall, J. (eds) (2013, 2015), Barthes' Mythologies Today:

Readings of Contemporary Culture, New York: Routledge Research in Media and Cultural Studies. 
(eds) (2016), Doing Text: Media After the Subject, Leighton Buzzard: Auteur

(forthcoming).

Bennett, P., Kendall, A. and McDougall, J. (2011), After the Media: Culture and

Identity in the 21st Century, London: Routledge.

Bingham, C. and Biesta, G. and Ranciere, J. (2010), Jacques Ranciere: Education,

Truth, Emancipation, London: Continuum.

Bernstein, B. (1996), Pedagogy, Symbolic control and Identity: theory, Research,

Critique, London, UK: Taylor and Francis.

Bowman, P. (2011), Reading Rancière: Critical Dissensus, London: Continuum.

(2012), 'Ranciere and the disciplines', paper presented at Crossroads in

Cultural Studies, Paris, June 2012.

Cobley, P. (2006), Barthes" sign theory in anglophone media and cultural studies', in

A. Ponzio, P. Calefato and S. Petrilli (eds), Con Roland Barthes alle sorgenti del senso/With Roland Barthes to Sense Sources, Rome: Meltemi. Meltemi.
Comment [K12]: Please provide the date and month.

Comment [K13]: Please provide the translation of the article title, if appropriate and page range. When you do this please follow the following format exactly, including connecting

punctuation: Cobley, P. (2006), “"Barthes" sign theory in anglophone media and

cultural studies', in A. Ponzio, P. Calefato and S. Petrilli (eds), Con Roland Barthes alle sorgenti del senso/xxx xxx xxx, Rome: Meltemi, pp. $\mathrm{xx}-\mathrm{xx}$. 
Cormier, D. (2008), 'Rhizomatic education: Community as curriculum', Innovate, $\underline{4}$ (5). http://www.innovateonline.info/index.php?view=article\&id=550. Accessed

\section{$\underline{3.3 .16}$}

Deleuze, G. (1994), Difference and Repetition, New York: Columbia University Press.

Deleuze, G. and Guattari, F. (2004), A Thousand Plateaus, London: Continuum.

Derrida, J. (1981), The Deaths of Roland Barthes in Silverman, K. (1988). Philosophy and Non-Philosophy Since Merleau-Ponty, Evanston: Northwestern University Press, pp. 259-96.

Drew, L. and Shreeve, A. (2012), 'A question of values, practice and pedagegy', Art, Design and Communication in Higher Education, 11:1, pp. 3-4=

Fairclough, N. (1995), Critical Discourse Analysis: The Critical Study of Language, London: Longman.

Gauntlett, D. (2015), Making Media Studies : The Creativity Turn in Media and Communications Studies, New York: Peter Lang.

Holland D and Quinn N. (eds) (1998). Identity and agency in cultural worlds. Harvard University Press: Cambridge MA.
Comment [K14]: Please provide the page range. When you do this please follow the following format exactly, including connecting punctuation: Cormier, D. (2008), 'Rhizomatic education: Community as curriculum', Innovate, 4:5, pp. $\mathrm{xx}-\mathrm{xx}$. ONLINE JOURNAL, NO PAGES.

Formatted: Font color: Auto Comment [K15]: Please provide the page range. When you do this please follow the following format exactly, including connecting punctuation: Drew, L. and Shreeve, A. (2012), 'A question of values, practice and pedagogy', Art, Design and Communication in Higher Education, $11: 1$, pp. $\mathrm{xx}-\mathrm{xx}$.

Formatted: Font: (Default) Times New Roman

Formatted: English (U.K.) 
Hughes, D. (2014), 'Dwelling as an approach to creative pedagogy', Art, Design and Communication in Higher Education, 13:1, pp. 73-87.

McDougall, J and Potter, J .(2015), 'Curating Media Learning' . Journal of E-Learning and Digital Media 12(2), pp,199-211

Masterman, L (ed). (1985) Television Mythologies: Stars, Shows and Signs. London: Marion Boyars.

Orr, S. and McDougall, J. (2014). 'Enquiry into learning and teaching in arts and creative practice', E. Cleaver, M. Lintern and M. McLinden (eds), Teaching and Learning in Higher Education: Disciplinary Approaches to Educational Enquiry, London: Sage, pp.162-177.

Rancière, J. (1991), The Ignorant Schoolmaster: Five Lessons in Intellectual Emancipation, California: Stanford University Press.

Rancière, J. (2009). The Emancipated Spectator. London: Verso.

Formatted: Font: Times New Roman

\section{Sherlock (2010-current / UK / BBC)}

Simons, M. and Masschelein, J. (2011), Ranciere, Public Education and The Taming of Democracy, Oxford: Wiley-Blackwell.
Formatted: Font: (Default) Times

Formatted: Font: (Default) Times New Roman

Formatted: Font: (Default) Times New Roman

Formatted: Font: Times New Roman New Roman

\section{Sherlock (2010-current/UK/BBC)}

of Democracy, Oxford: Wiley-Blackwell. 
Sontag, S. (1993), 'On Roland Barthes', in S. [K1] Sontag (ed.), A Roland Barthes

Reader, London: Vintage, pp. vii-xxxvi

\section{Top Gear, (2002- current, UK / BBC).}

Turner, G. (2012), What's Become of Cultural Studies?, London: Sage.

\section{The X Factor (2004-current, UK / ITV).}

\section{Contributor details}

Peter Bennett is Senior Lecturer in Post-Compulsory Education at the University of

Wolverhampton, UK. He is the co-author of After the Media: Culture and Identity in the 21st

Century (2011), and co-editor of Barthes' New Mythologies (2013) and both Doing Text:

Media after the Subject (forthcoming, 2016) and Popular Culture and the Austerity Myth:

Hard Times Today (forthcoming, 2016). He is also the co-author and co-editor of a range of

Communications, Media and Film textbooks, as well as Framework Media Channels (2003).

He is the co-author and Chief Examiner of Communication and Culture, A level, and a regular provider of INSET to teachers.

Julian McDougall is a Professor of Media and Education and Head of the Centre for

Excellence in Media Practice at Bournemouth University, where he leads the Educational Doctorate in Creative and Media Education. He is editor of the Media Education Research Journal and the Journal of Media Practice and author of a range of journal articles as well as academic books and student textbooks in the fields of media education, media/cultural studies and media literacy. Julian is currently working on research projects with Samsung and the United Kingdom Literacy Association, and has previously conducted research and knowledge
Formatted: Font: (Default) Times New Roman

Formatted: Font: (Default) Times New Roman

Formatted: Font: Italic

Formatted: Font color: Auto

Formatted: Font color: Orange

Formatted: Font: (Default) Times

New Roman

Formatted: Font: (Default) Times New Roman, 11 pt

Formatted: Font: (Default) Times New Roman 
exchange projects for the European Union, AHRC, ESRC and for the Media Education Association/Sixteen Films with the director Ken Loach.

Formatted: Font: $11 \mathrm{pt}$

Contact:

$\underline{\text { Professor Julian McDougall }}$

Centre for Excellence in Media Practice

Bournemouth University

Fern Barrow

$\underline{\text { Poole }}$

$\underline{\text { Dorset }}$

BH12 5BB

Julian@cemp.ac.uk

Formatted: Font: $11 \mathrm{pt}$

Formatted: Font: $11 \mathrm{pt}$ 